\title{
Analysis of Anti-Biofilm Activities of Extracts from Marine Invertebrate Collected from Izmir Bay (Eastern Aegean Sea)
}

\author{
Marcello Casertano ${ }^{1}$, Sibel Avunduk ${ }^{2}$, Asli Kacar ${ }^{3}$, Burcu Omuzbuken ${ }^{3}$, Marialuisa Menna ${ }^{1}$, Paolo \\ Luciano $^{1}$, Anna Aiello ${ }^{1}$ and Concetta Imperatore ${ }^{1 *}$ \\ ${ }^{1}$ Department of Pharmacy, University of Naples Federico II, Italy \\ ${ }^{2}$ Vocational School of Health Care, Marmaris Mugla, Turkey
}

${ }^{3}$ DEU Institute of Marine Sciences and Technology, Inciralti Izmir, Turkey

*Corresponding author: Concetta Imperatore, Department of Pharmacy, University of Naples "Federico II", Via D. Montesano 49, 80131 Napoli, Italy

\section{ARTICLE INFO}

Received: 㓞 July 30, 2019

Published: 幽 August 09, 2019

Citation: Marcello Casertano, Sibel Avunduk, Asli Kacar, Burcu Omuzbuken, Marialuisa Menna, Paolo Luciano, Anna Aiello, Concetta Imperatore. Analysis of Anti-Biofilm Activities of Extracts from Marine Invertebrate Collected from İzmir Bay (Eastern Aegean Sea). Biomed J Sci \& Tech Res 20(3)-2019. BJSTR. MS.ID.003449.

Keywords: Marine Invertebrate; Sponge; Tunicate; Marine Natural Products; Bioassay-Guided Fractionation; Fouling; Anti-Biofilm Activity

\begin{abstract}
In the maritime industry, biofouling is a severe problem and represents a serious matter of economic losses worldwide. The sizable investments are made for the prevention of biofouling by marine related sectors, especially in the paint industries. It is known that antifouling applications contain heavy metal and biocides which are hazardous for the marine environment and, for this reason, new studies are focusing on the development of environmentally and friendly paints. The main target of our investigation was the identification of natural marine compounds from tunicate and sponge species, evaluating their capability to inhibit biofilm progress which is the first step of fouling process, and their plausible usage in industrial products, too. Therefore, in this study, the antibiofilm effects of four marine invertebrates, Styela plicata, Clavelina lepadiformis, Dysidea avara and Spirastrella sp., collected in different seasons along the coasts of Izmir Bay, were evaluated. The extracts from two tunicates (Styela plicata and Clavelina lepadiformis) and a sponge (Dysidea avara) were selected due to their interesting antibiofilm capacities. A bioactive-guided isolation method allowed us to identification of the active fractions which were tested for inhibition of bacterial adhesion at different concentration. The content of the active fractions was identified by NMR spectroscopy, LC-MS and HRMS analysis.
\end{abstract}

Abbreviations: TBT: Tributyltin; FA: Formic Acid; CR: Percentage Reduction

\section{Introduction}

Biofilm is known as a community which formed by a series of microorganisms and macroorganisms on natural and artificial surfaces in seawater. Costerton et al. have defined biofilms for the first time in 1978 [1], and the biofilms have been an active research domain for science and technology. Actually, the biofilm formation involves important consequences for the efficient and harmless fulfilment of marine activities. Nevertheless, there are several methods to fighting biofilms, such as physical, mechanical and chemical removal. Unfortunately, colonies forming biofilms are often highly resistant to these approaches and despite they are efficient as remedies for antibiofilm elimination, they could transform in adverse elements for the environment. In the past, a consistent number of toxic substances (e.g. mercury, copper, arsenic and/or lead) but also organotin additives such as Tributyltin (TBT) have been effectively utilized to control the composition and the physical chemical characteristics of fouling before the International Maritime Organization (IMO) ban [2]. Subsequently, the strategies of antifouling were focused on characterization and advancement of products more friendly for the environment and were built on the defense mechanisms of marine organisms that sustain their body disengage of fouling [2]. Marine organisms including primarily invertebrates have developed a potential defense system 
since their evolution process to survivability. For this reason, the products of their metabolism represent a notable source of nontoxic antifouling compounds with the marine habitats as a prolific area for novel bioactive compounds or a source of repurposing agents, too [3].

However, the studies of the metabolic content from marine organisms, i.e. sponges, became an established discipline approximately fifty years ago when new instruments and technologies for the material collection were improved and commercially available. Thence forward, marine natural metabolites represent an almost unlimited source for the identification of novel chemical structures that might serve as a basis for the development of new drugs [4]. Therefore, the marine organisms provide an almost unlimited source both for the identification of novel chemical structures, that might serve as a basis for the development of new antifouling compounds, and for the discover of further properties of several known compounds. In addition to the studies on marine sponges, an interesting source is represented by the natural products that have been isolated from tunicates, in particular ascidians, accompanying used powerfully bioactive compounds $[5,6]$.

These compounds have been notified as dealing against biofouling species with weak toxicity and were newly well-regarded as forms to the synthesis of nature-spreads of antifouling agents namely zosteric acid $[7,8]$, batatasin III $[9,10]$, synoxazolidinone A [11], polygodial [12] and 2,5-diketopiperazine [13]. Further analyses, instead, have been led to evaluate the improvement of antifouling agents without the use of toxic materials carrying out interesting and positive feedback by different secondary metabolites from sponges as well as the 3-alkyl pyridinium salts $[14,15]$, isocyanoterpenoids [16] and from halogenated 1-methyl gramines based on a bryozoan [17].

According to the high potential of the research in this field and in continuation of our ongoing search for biologically active secondary metabolites from marine organisms [18-26], our present work reports the potential antifouling activities of twelve extracts obtained from marine invertebrates collected in the Bay of Izmir and also the identification of the putative bioactive compounds fol-

Table 1: Classification of marine species, dry weight, and season/region collection.
\begin{tabular}{|c|c|c|c|}
\hline \multirow{2}{*}{ Classification } & Organism & Collection season/Region & Dry weight \\
\hline \multirow{2}{*}{ Tunicate } & S. plicata & Summer/İnciraltı & $17.97 \mathrm{~g}$ \\
\cline { 2 - 4 } & C. lepadiformis & Fall /Konak & $14.65 \mathrm{~g}$ \\
\hline \multirow{2}{*}{ Sponge } & D. avara & Summer/Narlidere & $30.28 \mathrm{~g}$ \\
\cline { 2 - 4 } & Spirastrella sp. & Summer/Narlidere & $9.20 \mathrm{~g}$ \\
\hline
\end{tabular}

The pharmacological tests allowed to note as only buthanolic materials of the tunicate $S$. plicata was featured of an interesting antifouling activity and so it was further investigated. The $572.5 \mathrm{mg}$ of n-BuOH extract from S. plicata were chromatographed on $\mathrm{SiO}_{2}$ gel open column using a gradient elution starting from $\mathrm{CH}_{2} \mathrm{Cl}_{2} 100 \% \rightarrow$ lowing bioassay-guided fractionation. In this view, three of the most promising extracts were selected, two from tunicates (Styela plicata and Clavelina lepadiformis) and one from a sponge (Dysidea ava$r a$ ), and after a partial purification their composition was characterized using High Performance Liquid Chromatography coupled to Electrospray Mass Spectrometry (HPLC-ESI-MS) analysis, and NMR spectroscopy. In particular, it has been observed the active Styela sample contained

a. A monosaccharide constituted by six carbon atoms,

b. An organic acid, oxalic acid, along with

c. 24-nor-cholesta-5,22-dien-3- $\beta$-ol, a cholesterol derivative.

The Clavelina sample also contained a hexose sugar, due to the both cited samples are the polar fractions, and the amino acid isoleucine. The third interesting extract was a D. avara fractioned sample which included avarol and avarone, two of most common secondary metabolites isolated from this sponge and characterized by sesquiterpenoid skeleton $[27,28]$. The results reported in this study point out promising species for further and more detailed investigations.

\section{Materials and Methods}

\section{Sampling and Extraction}

The analyzed samples were collected in different seasons of 2016 from various regions of İzmir Bay in Turkey and kept frozen until used. Table 1 summarizes the classification, dry weight, and season/region collection of the marine tunicates, S. plicata and $C$. lepadiformis, and sponges, D. avara and Spirastrella sp. objects of our studies. After lyophilization, all samples were grinded and extracted with three different organic solvents: n-hexane, dichlorometane and methanol, using Soxhlet apparatus, respectively. In this way, all extracts were concentrated in vacuo recovering three different organic extracts per organism. Lastly, the methanolic phase of all samples was dissolved in water and partitioned with n-BuOH. To explore and identify any components of extracts responsible of antifouling activity, the active extracts of interest were further fractionated by open liquid chromatography and by HPLC purification, and then analyzed by LC-MS and 1D NMR.
Table 1: Classification of marine species, dry weight, and season/region collection.
$\mathrm{CH}_{2} \mathrm{Cl}_{2} / \mathrm{MeOH}(9: 1 \rightarrow 8: 2 \rightarrow 7: 3 \rightarrow 6: 4 \rightarrow 1: 1 \rightarrow 4: 6 \rightarrow 3: 7 \rightarrow 2: 8 \rightarrow 1: 9)$ ending with $\mathrm{MeOH} 100 \%$ to yield 11 fractions 1-11. Among these fractions, only the most polar $11(5 \mathrm{mg}$ ) was active and was beyond purified. The metabolic content was determined by LC-MS coupled by $\mathrm{ms} / \mathrm{ms}$ pathway analysis. In particular, we highlighted that this 
fraction contained a mixture of 1-0-nonyl 2-0-prop-2-enyl oxalate, 24-nor-cholesta-5,22-dien-3- $\beta$-ol, and a monosaccharide with six carbons as reported in Table 2, showed an interesting antibiofilm activity.

Table 2: Metabolite profile of $S$. plicata active fraction by LC-MS analysis.

\begin{tabular}{|c|c|c|c|c|c|c|}
\hline Substances NO & Retention time (min.) & Chemical formula & Name & Adduct & Adduct m/z & Mass Error (ppm) \\
\hline 1 & 2.86 & $\mathrm{C}_{6} \mathrm{H}_{12} \mathrm{O}_{6} \mathrm{Na}$ & hexose & {$[\mathrm{M}+\mathrm{Na}]+$} & 203.0532 & 0.641 \\
\hline 2 & 36.91 & $\mathrm{C}_{14} \mathrm{H}_{24} \mathrm{O}_{4} \mathrm{Na}$ & 1-O-nonyl 2-O-prop-2-enyl oxalate & {$[\mathrm{M}+\mathrm{Na}]+$} & 279.1595 & 2.87 \\
\hline 3 & 38.46 & $\mathrm{C}_{26} \mathrm{H}_{26} \mathrm{O}$ & 24-nor-Cholesta-5,22-dien-3- $b$-ol & {$[\mathrm{M}+\mathrm{H}]+$} & 371.328 & 3.736 \\
\hline
\end{tabular}

The C. lepadiformis powder was exhaustively extracted with n-hexane, $\mathrm{CH}_{2} \mathrm{Cl}_{2}$ and $\mathrm{MeOH}$ respectively at room temperature. The $\mathrm{MeOH}$ extract was evaporated till dryness, dissolved in water and partitioned three times between $\mathrm{n}-\mathrm{BuOH}$ and water to eliminate salt and complex polysaccharides. The antibiofilm activity of crude n-hexane, $\mathrm{CH}_{2} \mathrm{Cl}_{2}$, and n-BuOH extracts was evaluated. Only the most polar material (n-BuOH extract) showed to be active, and it was subjected to the same open column chromatography procedure reported above for the $S$. plicata. Only the fraction eluted with a mixture $\mathrm{CH}_{2} \mathrm{Cl}_{2} / \mathrm{MeOH}$ (1:9) resulted active and, therefore, was subjected to LC-MS analysis. This fraction contained primarily a hexose, isoleucine, and Ne-myristoyl-L-lysine-methyl ester (Table $3)$.

Table 3: Metabolite profile of C. lepadiformis fraction by LC-MS analysis.

\begin{tabular}{|c|c|c|c|c|c|c|}
\hline Substances NO & Retention time (min.) & Chemical formula & Name & Adduct & Adduct m/z & Mass Error (ppm) \\
\hline 1 & 2.71 & $\mathrm{C}_{6} \mathrm{H}_{12} \mathrm{O}_{6} \mathrm{Na}$ & hexose & {$[\mathrm{M}+\mathrm{Na}]+$} & 203.0534 & 0.771 \\
\hline 2 & 2.85 & $\mathrm{C}_{6} \mathrm{H}_{14} \mathrm{O}_{2} \mathrm{~N}$ & isoleucine & {$[\mathrm{M}+\mathrm{H}]+$} & 132.1023 & 0.425 \\
\hline 3 & 38.25 & $\mathrm{C}_{21} \mathrm{H}_{43} \mathrm{O}_{3} \mathrm{~N}_{2}$ & $\mathrm{~N}^{\varepsilon}$-myristoyl-L-lysine-methyl ester & {$[\mathrm{M}+\mathrm{H}]+$} & 371.3275 & 1.832 \\
\hline
\end{tabular}

The LC-MS/MS analysis of active S. plicata and C. lepadiformis buthanolic fractions was realized and a chromatographic separation was performed with a reversed phase liquid chromatography column (Luna $3 \mu \mathrm{M}$ C18 $4.6 \mathrm{~mm} \times 150 \mathrm{~mm}$ ). A gradient elution program was applied with two solvents (A) water and (B) $\mathrm{MeOH}$, both containing $0.1 \%$ of Formic Acid (FA). The applied gradient started from $30 \%$ of B, held for 3 minutes, which increased to $50 \%$ in $10 \mathrm{~min}$, further to $90 \%$ in $20 \mathrm{~min}, 100 \%$ of B in 5 min and finally held for 10 minutes. The column temperature was set at $26^{\circ} \mathrm{C}$ and an equilibration time of 15 min was kept after each sample run. Each analysis was performed with a flow rate was of $0.4 \mathrm{~mL} / \mathrm{min}$ and $30 \mu \mathrm{L}$ injection volume. High Resolution Electrospray Ionization (HRESIMS) in positive mode was used to ionize the metabolites on a Thermo LTQ Orbitrap XL mass spectrometer (Thermo-Fisher, San Josè, CA, USA) using $\mathrm{MeOH}$ as solvent.

Regarding the studies on the sponge D. avara, from pharmacological screening the n-hexane extract resulted of interest. To identify the bioactive compounds able to show antifouling activity, the n-hexane soluble material was submitted to NP-silica gel open column using a gradient elution: n-hexane $100 \% \rightarrow$ n-hexane/EtOAc
$(9: 1 \rightarrow 8: 2 \rightarrow 7: 3 \rightarrow 6: 4 \rightarrow 1: 1 \rightarrow 4: 6 \rightarrow 3: 7 \rightarrow 2: 8 \rightarrow 1: 9) \rightarrow$ EtOAc $100 \%$. This purification led to 11 fractions and, among these, fraction 10 (125.4 mg) was picked for antibiofilm activity and resulted to be effective. In the aim to identify the bioactive metabolites and considering the good availability of this active fraction, we decided to separate into individual compounds the material using HPLC procedure. In particular, since the NMR analysis allowed to define the presence of sesquiterpenoids compounds, fraction 10 of D. avara was chromatographed on a reverse phase column (Luna $5 \mu \mathrm{M} \mathrm{C18,}$ flow rate $1 \mathrm{~mL} / \mathrm{min}$.) and a mixture of $\mathrm{MeOH} / \mathrm{H}_{2} \mathrm{O} 95: 5(\mathrm{v} / \mathrm{v} \%)$ as mobile phase afforded two pure compounds avarol (15.6 mg, tR $5.4 \mathrm{~min}$.) and avarone (26.2 $\mathrm{mg}$, tR $9.4 \mathrm{~min}$ ) as reported in Table 4. These well-known secondary metabolites of $D$. avara were univocally identified by the comparison of 1 H NMR chemical shift recorded for avarol and avarone with those of already reported in literature $[27,28]$. The $1 \mathrm{H}$ NMR $(500 \mathrm{MHz})$ spectra of the sesquiterpenoid hydroquinone, avarol, and of its quinone derivative, avarone, were recorded with an Agilent INOVA spectrometer (Agilent Technology, Cernusco sul Naviglio, Italy) and chemical shifts were referenced to the residual solvent signal $\left(\mathrm{CDCl}_{3}: \delta \mathrm{H}=7.26, \delta \mathrm{C}=77.0\right)$.

Table 4: Metabolite profile of D. avara fraction by MS analysis.

\begin{tabular}{|c|c|c|c|c|c|c|}
\hline Substances NO & Retention time (min.) & Chemical formula & Name & Adduct & Adduct m/z & Mass Error (ppm) \\
\hline 1 & 5.4 & $\mathrm{C}_{21} \mathrm{H}_{31} \mathrm{O}_{2}$ & avarol & {$[\mathrm{M}+\mathrm{H}]+$} & 315.2322 & 1.089 \\
\hline 2 & 9.4 & $\mathrm{C}_{21} \mathrm{H}_{29} \mathrm{O}_{2}$ & avarone & {$[\mathrm{M}+\mathrm{H}]+$} & 313.2173 & 3.491 \\
\hline
\end{tabular}

A sponge sample of Spirastrella $s p$. was collected in the Summer along the coast of Narlidere and exhaustively extracted with n-hexane, $\mathrm{CH} 2 \mathrm{Cl} 2$ and $\mathrm{MeOH}$ following the same procedure reported above. The antibiofilm activity of each crude extract was evaluated but no effect has been showed. 


\section{Test Microorganisms}

The biofilm-forming bacteria were isolated from a biofilm on panel systems immersed in the bay of Izmir (Turkey). A comparative 16S rRNA gene sequence analysis indicated that the isolates belonged to the species Exiguobacterium homiense FJ200653. The bacterial suspension was prepared from biofilm bacteria grown overnight on Zobell Marine Medium (Difco) at $26^{\circ} \mathrm{C}$ to reach an OD600 value of 2 .

\section{Anti-Biofilm Activity Test}

Various concentrations of the examined extracts and fractions of S. plicata, C. lepadiformis, D. avara, and Spirastella sp. were experimentally tested as eco-friendly antifouling additives over the biofilm bacteria.

The assay was performed and modified as described by Leroy et al. [29] and Aykin et al. [30,31]. Briefly, the test of biofilm bacteria adhesion in black polystyrene flat-bottomed microplates (Greiner Bio One, Austria) was performed in sterile seawater at $20^{\circ} \mathrm{C}$.

The dilution of the different samples obtained from the above cited sponges and tunicates were tested in order to evaluate the inhibition percentage of bacterial adhesion. $50 \mu \mathrm{l}$ of the dilution at different concentrations of each sample (1/2 to $1 / 32 \mathrm{ml}-1)$ were placed in the wells 1 hour before introducing the bacterial suspension ( $200 \mu \mathrm{l}$ per well) and then incubated for 24 hours at $20^{\circ} \mathrm{C}$ using orbital shaking $(120 \mathrm{rpm})$ in order to perform the prevention test. After the incubation with shaking, three washes with a water solution of sodium chloride were performed before fixing for 1.5 hours at $4^{\circ} \mathrm{C}$ with $200 \mu$ of sterile $\mathrm{NaCl}$ - containing
2.5\% formaldehyde and DAPI staining ( $4 \mu \mathrm{g} \mathrm{ml}-1$ ) - for 20 minutes. Fluorescence was measured at $350 \mathrm{~nm}$ as light excitation and $510 \mathrm{~nm}$ as light emission wavelengths using a Synergy HTX multimode reader (Biotek, USA). A blank with sterile seawater as well as a control with only the presence of bacterial suspension was added in each column of the microplate.

The effect of the change in term of bacterial adhesion was calculated as the Percentage Reduction (CR) by comparing it to the fluorescence of the blank (FB: without bacteria), the fluorescence of the control (FC: bacteria without dilution of tested fraction) and the fluorescence of the sample (FS: bacteria with a certain dilution of sample) according to:

$$
C R=\{[(F C-F B)-(F S-F B)] /(F C-F B)\} \times 100
$$

\section{Results and Discussion}

We included the n-hexane, dichloromethane and n-BuOH extracts of each marine organism into pharmacological screening in order to evaluate the percentage of inhibition of the bacterial adhesion using Exiguobacterium homiense as marine biofilm bacteria. The resulting active extracts (n-BuOH of $S$. plicata, n-BuOH of C. lepadiformis and n-hexane of D. avara) were further investigated by a bioassay-guided fractionation identifying three active fractions which facility to prevent the biofilm development on the polystyrene microplate is showed in Figure 1. The results showed that the biofilm bacteria, Exiguobacterium homiense, were significantly affected during the 24-hour incubation process of the prevention test. Indeed, the active fractions were potent additives as highlighted by the calculated CR50 dilution values of these fractions.

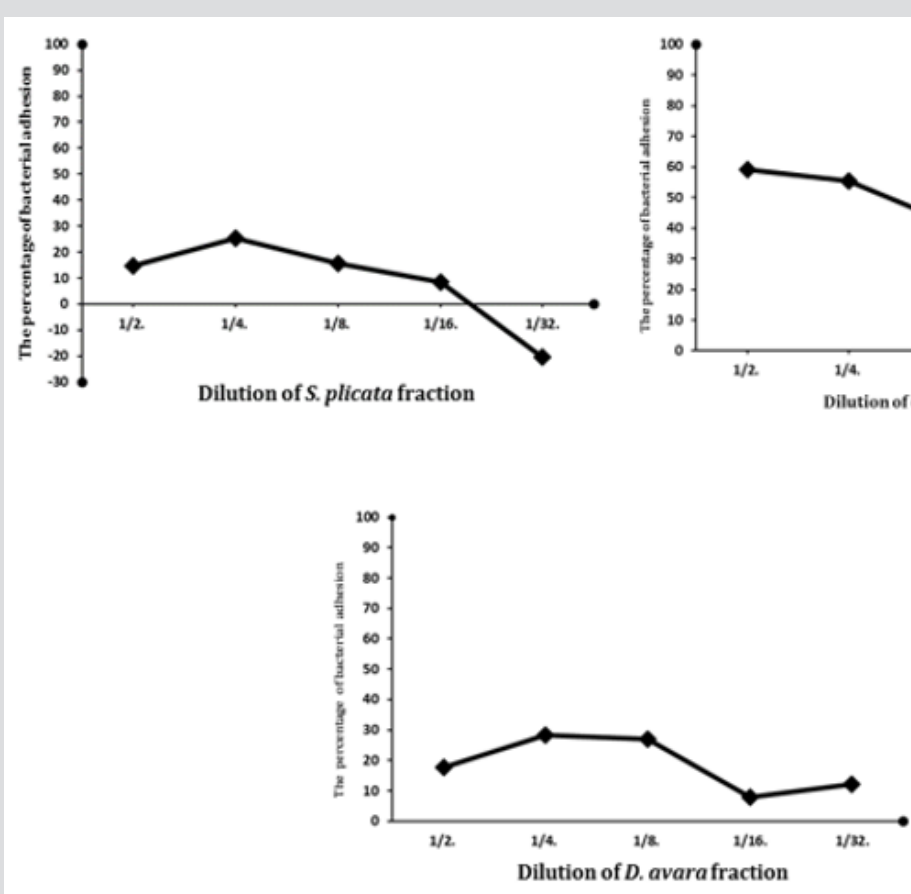

Figure 1: The change in bacterial adhesion in relation to dilution of the most relevant fractions from S. plicata, C. lepadiformis and D. avara, respectively. 
Definitely, n-BuOH extracts of C. lepadiformis and S. plicata provided the two most effective fractions accomplishing the highest reduction percentage of all the bacterial isolates. The bacterial settlement and biofilm formation represent the first steps of fouling process which is a serious problem with economic implications. On this basis, this situation demands new strategies against biofilm formation with antibiofilm agents that are specific to biofilms but are not toxic. A few antimicrobial investigations were also carried out on some species of the marine sponge with the aim to detect antibacterial effects of marine sponges and tunicates. Orhan et al. evaluated the antibacterial properties of the extracts of various marine sponges (Dysidea avara, Axinella cannabina, Ircinia fasciculate, I. spinulosa, I. variabilis, Sarcotragus spinulosus, Agelas oroides and Axinella damicornis) collected from different places of the Turkish marine environments from the Mediterranean Sea [32]. The occurrence of a locational diversity in antibacterial activity was observed within the extracts of the similar sponge species gathered from varied coastal regions. According to their studies, we collected and analyzed the metabolic content of sponge and tunicate species from different area of Eastern Aegean coast. Here, a number of active antifouling compounds has been identified from the tunicates $S$. plicata and C. lepadiformis and from the sponge $D$. avara. The structural elucidation of the content of these fractions was performed by NMR spectroscopy, LC-MS/MS and HRESI mass spectrometry. Once a time marine environment represents a prolific source of bioactive compounds. In the future, further assays are arranged to determine how specific and broadly active these marine metabolites are.

\section{References}

1. Costerton JW, Geesey GG, Cheng KJ (1978) How bacteria stick. Sci Am 238(1): 86-95.

2. Qian PY, Xu Y, Fusetani N (2010) Natural products as antifouling compounds: recent progress and future perspectives. Biofouling 26(2): 223-234.

3. Fusetani N (2004) Biofouling and antifouling. Nat Prod Rep 21(1): $94-$ 104.

4. Hamed I, Ozogul F, Ozogul Y, Regenstein JM (2015) Marine Bioactive Compounds and Their Health Benefits: A Review. Compr Rev Food Sci F 14(4): 446-465.

5. Blunt JW, Carroll AR, Copp BR, Davis RA, Keyzers RA, et al. (2010) Marine natural products. Nat Prod Rep 27(2): 165-237.

6. Blunt JW, Copp BR, Munso MH, Northcote PT, Prinsep MR (2011) Marine natural products. Nat Prod Rep 28(2): 196-268.

7. Almeida JR, Correia-Da-Silva M, Sousa E, Antunes J, Pinto M, et al. (2017) Antifouling potential of nature-inspired sulfated compounds. Sci Rep 7: 42424-42435.

8. Catto C, Dell'Orto S, Villa F, Villa S, Gelain A, et al. (2015) Unravelling the structural and molecular basis responsible for the anti-biofilm activity of zosteric acid. PLoS One 10: e0131519.

9. Moodie LW K, Trepos R, Cervin G, Brathen KA, Lindgard B, et al. (2017) Prevention of marine biofouling using the natural allelopathic compound batatasin-III and synthetic analogues. J Nat Prod 80(7): 2001-2011.

10. Moodie LW K, Cervin G, Trepos R, Labriere C, Hellio C, et al. (2018) Design and biological evaluation of antifouling dihydrostilbene oxime hybrids. Mar Biotechnol 20(2): 257-267.
11. Trepos R, Cervin G, Hellio C, Pavia H, Stensen W, et al. (2014) Antifouling compounds from the sub-arctic ascidian synoicum pulmonaria: synoxazolidinones $\mathrm{A}$ and $\mathrm{C}$, pulmonarins $\mathrm{A}$ and $\mathrm{B}$, and synthetic analogues. J Nat Prod 77(9): 2105-2113.

12. Moodie LW K, Trepos R, Cervin G, Larsen L, Larsen DS, et al. (2017) Probing the structure-activity relationship of the natural antifouling agent polygodial against both micro- and macrofoulers by semisynthetic modification. J Nat Prod 80(2): 515-525.

13. Liao S, Xu Y, Tang Y, Wang J, Zhou X, et al. (2015) Design, synthesis and biological evaluation of soluble 2,5-diketopiperazines derivatives as potential antifouling agents. RSC Adv 5(63): 51020-51026.

14. Chelossi E, Mancini I, Sepcic K, Turk T, Faimali M (2006) Comparative antibacterial activity of polymeric 3-alkylpyridinium salts isolated from the Mediterranean sponge Reniera sarai and their synthetic analogues. Biomol Eng 23: 317-323.

15. Elersek T, Kosi G, Turk T, Pohleven F, Sepcic K (2008) Influence of polymeric 3-alkylpyridinium salts from the marine sponge Reniera sarai on the growth of algae and wood decay fungi. Biofouling 24(2): 137-143.

16. Nogata Y, Kitano Y (2006) Isocyano compounds as non-toxic antifoulants. Prog Mol Subcell Biol 42: 87-104.

17. Kawamata M, Kon-ya K, Miki W (2006) 5,6-Dichloro-1-methylgramine a non-toxic antifoulant derived from a marine natural product. Prog $\mathrm{Mol}$ Subcell Biol 42: 125-139.

18. Menna M, Aiello A, D’Aniello F, Fattorusso E, Imperatore C, et al. (2012) Further investigation of the mediterranean sponge Axinella polypoides: Isolation of a new cyclonucleoside and a new betaine. Mar Drugs 10(11): 2509-2518.

19. Imperatore C, Persico M, Aiello A, Luciano P, Guiso M, et al. (2015) Marine inspired antiplasmodial thiazinoquinones: Synthesis, computational studies and electrochemical assays. RSC Adv 5(86): 70689-70702.

20. Imperatore C, Luciano P, Aiello A, Vitalone R, Irace C, et al. (2016) Structure and Configuration of Phosphoeleganin, A Protein Tyrosine Phosphatase 1B Inhibitor from the Mediterranean Ascidian Sidnyum elegans. J Nat Prod 79(4): 1144-1148.

21. Luciano P, Imperatore C, Senese M, Aiello A, Casertano M, et al. (2017) Assignment of the Absolute Configuration of Phosphoeleganin via Synthesis of Model Compounds. J Nat Prod 80(7): 2118-2123.

22. Imperatore C, Cimino P, Torrejon CG, Persico M, Aiello, A, et al. (2017) Insight into the mechanism of action of marine cytotoxic thiazinoquinones. Mar Drugs 15(11): E335.

23. Imperatore C, Persico M, Senese M, Aiello A, Casertano M, et al. (2019) Exploring the antimalarial potential of the methoxy-thiazinoquinone scaffold: Identification of a new lead candidate. Bioorg Chem 85: 240252.

24. Imperatore C, D’Aniello F, Aiello A, Fiorucci S, D’Amore C, et al. (2014) Phallusiasterols A and B: Two new sulfated sterols from the Mediterranean tunicate Phallusia fumigata and their effects as modulators of the PXR receptor. Mar Drugs 12(4): 2066-2078.

25. Imperatore C, Senese M, Aiello A, Luciano P, Fiorucci S, et al. (2016) Phallusiasterol C, A New Disulfated Steroid from the Mediterranean Tunicate Phallusia fumigata. Mar Drugs 14(6): 117-124.

26. Casertano M, Imperatore C, Luciano P, Aiello A, Putra MY, et al. (2019) Chemical Investigation of the Indonesian Tunicate Polycarpa aurata and Evaluation of the Effects Against Schistosoma mansoni of the Novel Alkaloids Polyaurines A and B. Mar Drugs 17(5): 278-289.

27. Minale L, Riccio R, Sodano G (1974) Avarol, a novel sesquiterpenoid hydroquinone with a rearranged drimane skeleton from the sponge Dysidea avara. Tetrahedron Lett 15(38): 3401-3404.

28. Rosa DS, Minale L, Riccio R, Sodano G (1976) The absolute configuration of avarol, A rearranged sesquiterpenoid hydroquinone from a marine sponge. J Chem Soc Perkins Trans 1: 1408-1414. 
29. Leroy C, Delbarre C, Ghillebaert F, Compere C, Combes D (2008) Effects of commercial enzymes on the adhesion of a marine biofilm-forming bacterium. Biofouling 24(1): 11-22.

30. Aykin E, Omuzbuken B, Kacar A (2018) Antibiofilm Potential of Enzymes Ecofriendly Antifouling Additives. Fresen Environ Bull 27(6): 40934103.

\section{ISSN: 2574-1241}

DOI: 10.26717/BJSTR.2019.20.003449

Concetta Imperatore. Biomed J Sci \& Tech Res

(c) This work is licensed under Creative

Submission Link: https://biomedres.us/submit-manuscript.php
31. Aykin E, Omuzbuken B, Kacar A (2019) Microfouling Bacteria and the Use of Enzymes in Ecofriendly Antifouling Technology. J Coat Technol Res 16(3): 847-856.

32. Orhan IE, Ozcelik B, Konuklugil B, Putz A, Kaban UG, et al. (2012) Bioactivity Screening of the Selected Turkish Marine Sponges and Three Compounds from Agelas oroides. Rec Nat Prod 6(4): 356-367.

$\begin{array}{ll}\text { BIOMEDICAL } & \text { Assets of Publishing with us } \\ \text { RESEARCHES } & \text { - Global archiving of articles } \\ \text { - Immediate, unrestricted online access } & \text { - Rigorous Peer Review Process } \\ & \text { - Authors Retain Copyrights } \\ & \end{array}$

